\title{
TRAINING RENOVASI DAN PERAWATAN POMPA HIDRAM \\ DI DESA KARANG PELEM, KECAMATAN KEDAWUNG, SRAGEN
}

\author{
Aliem Sudjatmiko,Qunik Wiqoyah dan M. Ujianto \\ Jurusan Sipil-Fakultas Teknik \\ Universitas Muhammadiyah Surakarta
}

\section{ABSTRACT}

Technological Pump the Hidram technology pump to use the base work style of grafitasi earth and designed in such a way till work the pump work automatically without there external energi for example energi oil. Constraint which often bother the [job/activity] pump the hidram is not optimal is component function pump the effect stuffing up of dirt and component damage pump. The pump Hidram equiped some kinds of spillway, for example functioning water spillway to arrange awaking of current and awaking of pressure irrigate the, air-trap to arrange awaking of air composition in water. Especial benefit air good for condition of [is nature of water from nature of water which incompresible become semi incompresible so that punching influence irrigate the/hummer water not destroy the material pump specially save the tekan.Tabung depress to function to catch and maintain the yielded water pressure. Component pump the hidram consisted of the Reservoir concentration, fast pipe, spillway of limbah,balance weight, air spillway, spillway depress and save to depress and also other supporter that is pipe between. In course of evaluation [done/conducted] repair problem of water spillway using rubber of vehicle rut/rubber konveyor, and if/when reckoned from a economic side pump this very efficient because energi used to create the pressure irrigate to come from laboring earth gravitation style air.Benefit from spillway irrigate and also air spillway can be arranged in such a way till work the pump can work automatically and will labour on during balance constraint work the pump not annoyed. From repair result got a technical age spillway mount and stay more 6 month; moon and loss / water leakage causing to lessen the pressure can be avoided. To the condition of in such a way till work the pump automatically [done/conducted] a trial and error

Kata kunci: pompa hidram,katup air,katup udara.

36 WARTA, Vol .10, No. 1, Maret 2007: 36 - 42 


\section{PENDAHULUAN}

Pompa Hidram yang terletak di desa Karang Pelem Kecamatan Kedawung Kabupaten Sragen adalah produk pengabdian masyarakat Lembaga Penelitian dan Pengabdian Masyarakat Universitas Muhammadiyah Surakarta (LPPM - UMS) tahun 1989 bekerjasama dengan Pemda TK-I Jawa Tengah dan Kopertis Wilayah VI dan sampai saat ini masih berjalan dan masih dimanfaatkan oleh masyarakat sekitar pompa. Adapun berdasarkan survey dan koordinasi tim Fakultas Teknik ke lokasi s/d bulan Juli 2005, team mengambil kesimpulan perlu adanya kegiatan ke lapangan dalam rangka training kegiatan kepada masyarakat tentang bagaimana cara perawatan dan penanggulangan problem pompa yang semakin lama semakin berkurang produktivitas dan aspek fungsi kerja pompa sesuai dengan keterangan laporan masyarakat disekitar pompa tersebut dibangun (hasil wawancara pendahuluan dengan pengelola/pengguna di lapangan).

Selama ini masyarakat melakukan perawatan dengan metode versi lama mengikuti doktrin program yang pada saat pembangunan dilakukan. Namun dengan perkembangan waktu dan perkembangan pemikiran, cara perawatan dan renovasi perlu disesuaikan dengan hasil penyempurnaan/analisa yang terbaru, tentunya mengikuti dan mengacu hasil penyempuranaan tim Fakultas Teknik UMS khususnya yang selama ini mengamati perkembangkan pompa Hidram.

Berdasarkan hasil inventarisasi analisa referensi di lapangan, tim mendapatkan formulasi penyelesaian berupa bagaimana meningkatkan efisiensi dan mengawetkan fungsi katup baik katup air maupun katup udara agar tidak mudah rusak dan bagaimana cara penanggulangan kendala tersebut yaitu melalui training dengan simulasi alat peraga dan pembelajaran di lapangan langsung dengan masyarakat untuk membahas permasalahan yang ada

Dengan tetap berfungsinya Pompa Hidram di Desa Karang Pelem Kec kedawung Kab Sragen, maka hasil program pengabdian masyarakat yang bersifat monumental dari LPPM UMS tentang terapan IPTEK masih bisa dinikmati masyarakat di sekitar keberadaan pompa tersebut dibangun dan agar LPPM UMS tetap tampil di arena IPTEK untuk masyarakat .

Manfaat kegiatan aplikasi IPTEK:

1. Tetap dilakukannya pengembangan di bidang IPTEK tentang masalah pemanfaatan air melalui percobaan dan penelitian khususnya pompa Hidram. 
2. Menjadikan IPTEK agar selalu melekat dalam kehidupan masyarakat bukan hal yang sulit dilakukan oleh masyarakat, dan agar bisa merubah paradigma berfikir masyarakat tentang perlunya IPTEK. Sehingga menyatu dihati masyarakat, dan bisa dijadikan tempat rekreasi yang berbasis IPTEK terutama bagi siswa SD/SLTP/SLTA agar terpancing dengan sentuhan inovasi IPTEK khususnya tentang air dengan media pompa Hidram.

\section{METODE KEGIATAN.}

Metode yang digunakan adalah metode simulasi alat dan training lapangan

Tahapan kegiatan yang dilakukan tim adalah sebagai berikut

1. Pembuatan konsep peralatan yang disesuaikan dengan penyempurnaan design dan gambar-gambar simulasi tentang komponen pompa.

2. Pembuatan komponen contoh peralatan / komponen pompa hidram.

3. Mengadakan kegiatan pembelajaran / training lapangan pada pengguna / pengelola pompa.

4. Mengadakan simulasi langsung di lapangan dengan kelompok masyarakat pengguna air.

Realisasi Penyelesaian Masalah

1. Membuat perencanaan perbaikan desainn komponen pompa yang lebih handal utamanya katup limbah yang awet terhadap tekanan.

2. Membuat desain perangkat katup udara yang menjamin tersedianya udara dalam tabung tekan agar tabung tekan lebih awet.

3. Membuat desain tabung udara yang kuat dengan tekanan tinggi dan yang menjamin udara tidak keluar melalui arus air.

4. Membuat desain katup tabung tekan yang handal agar dijamin tidak terjadi arus balik yang menandakan katup kurang efektif.

Kegiatan ini diperuntukkan kepada masyarakat disekitar pompa yang selama ini telah mengelola keberlangsungan kehidupan pompa dan sebagai pengguna air sesuai dengan kemampuan kapasitas produksi air yang dihasilkan. Metode pembelajaran teoritis dan training dilakukan langsung di lokasi obyek pompa yang dibangun di desa Karang Pelem Kecamatan Kedawung Kabupaten Sragen dan lebih lanjut jadwal kegiatan ada pada tabel berikut:

38 WARTA, Vol.10, No. 1, Maret 2007: 36 - 42 


\begin{tabular}{|l|c|l|l|l|}
\hline No. & Hari/tanggal & \multicolumn{1}{c|}{ Kegiatan } & \multicolumn{1}{|c|}{ Lokasi } & \multicolumn{1}{c|}{ Pesrta } \\
\hline 1. & Minggu, 04-12-05 & Diskusi Materi & Rumah Penduduk & Pengguna Air \\
\hline 2. & Minggu, 11-12-05 & $\begin{array}{l}\text { Bongkar pompa dan } \\
\text { Training Lapangan }\end{array}$ & Lokasi pompa & Pengguna air \\
\hline 3. & Minggu, 18-12-05 & Evaluasi lapangan & Lokasi pompa & Pengelola \\
\hline
\end{tabular}

Aktivitas lapangan yang dilakukan dirancang sebagai berikut

1. Sesi pertama diskusi tentang pompa dengan materi pompa secara global.

2. Sesi ke dua berupa pembongkaran pompa serta diskusi tentang komponen terpasang.

3. Karena dengan secara langsung menangani permasalahan tidak menutup kemungkinan akan berkembang dengan pola diskusi di lokasi dan team memberikan naskah dokumen tulisan berisi berbagai penangan kesulitan di lapangan dan dilanjut dengan evaluasi riil lapangan.

\section{HASIL KEGIATAN DAN PEMBAHASAN}

Dalam program diskusi materi berkembang pemikiran tentang IPTEK di hati masyarakat dan banyak keinginan lain yang berbasis IPTEK, akan tetapi tim membatasi dengan materi tentang air. Dalam kesempatan ini ada materi usulan bagaimana cara mengoptimalkan air yang ada termasuk program distribusi air dengan aliran grafitasi yang selama ini mengalami kendala dan ini sudah dilakukan tim untuk memberi solusi yaitu dengan cara memberikan katup pernafasan udara pada saluran setiap 16 meter panjang saluran karena selama ini hal tersebut belum dilakukan agar perilaku aliran tidak terganggu oleh gelembung udara yang terperangkap dalam aliran air.Pemasangan katup diusahakan berposisi vertikal untuk menghindari asimetri beban yang mengakibatkan aus disalah satu sisi pada as luncur.Pada mulanya tim pernah mencoba bantuan pegas untuk membantu percepatan kembalinya katup pada posisi semula namun hasilnya kurang memuaskan/umur teknis terlalu pendek sehingga dimungkinkan terlalu sering bongkar pasang perbaikan pompa. Material pompa didominasi dari bahan besi, pipa antar dipilih pipa ukuran tebal/medium agar hummer water tidak cepat merusak pipa dan harus tahan terhadap tekanan tinggi sesaat.As luncur katup digunakan besi baja karena frekwensi gerak as kurang lebih satu langkah tiap 2 detik dan bisa diasumsikan bila kerja pompa penuh $24 \mathrm{jam} / \mathrm{hari}$ dan diharapkan bisa kerja selama 6 bulan/ masa evaluasi 


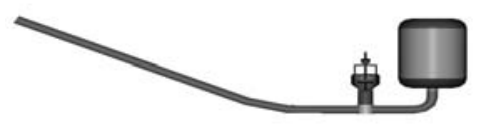

gambar : pompa Hidram

Katup limbah dalam rutinitas kerjanya menggunakan penuh gaya grafitasi yang direncanakan dengan dengan bantuan bandul parameter/beban parameter, kerja katup akan mengikuti frekwensi kerja sesuai yang direncanakan/hasil seting awal.
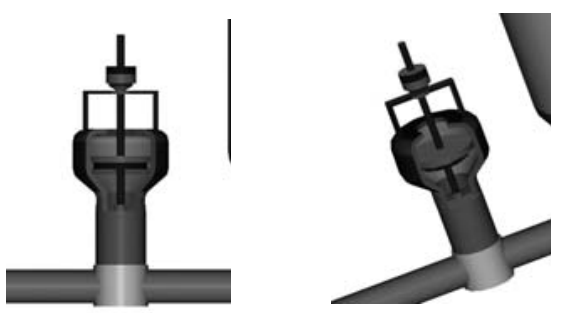

gambar : katup limbah

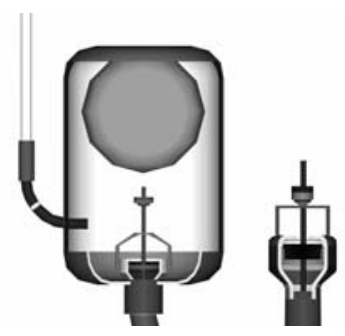

gambar : potongan tabung tekan

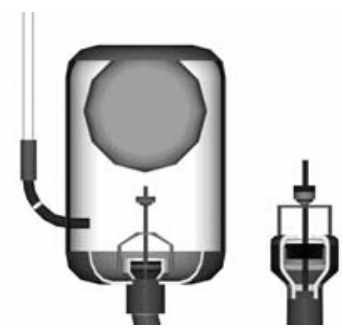

gambar : detail tabung tekan dan katup tekan 
Untuk kegiatan renovasi/perbaikan pompa hidram telah tersampaikan beberapa hal penting terkait dengan kendala-kendala yang sering muncul antara lain fungsi katup limbah yang terlalu longgar sehingga terlalu banyak energi yang terbuang, dan sudah disarankan celah katup limbah tidak lebih dari 4 $\mathrm{mm}$ artinya selisih diameter silinder dengan katup limbah tidak lebih dari 8 $\mathrm{mm}$. Mengenai katup udara perlu dibuat pada posisi vertical dengan maksud gaya grafitasi akan membantu mengembalikan posisi katup pada posisi semula Ada penyempurnaan tentang pipa antar dimana kondisi semula dibuat dengan diameter $1 / 2$ inci, dalam kegiatan ini disarankan untuk dirubah menjadi 1 inci dengan maksud aliran dari tabung tekan agar lebih lancar dan disarankan katup dibuat pada posisi vertikal dan dihindari jangan banyak terdapat belokan.

\section{SIMPULAN DAN SARAN}

\section{a. Simpulan}

1. Penggunaan karet limbah konveyor/ban bekas roda truk pada katup limbah bisa mencapai umur lebih dari 6 bulan.

2. Air yang masuk ke badan pompa harus selalu bebas dari kotoran yang berdampak pada penyumbatan/perlu dipasang saringan.

3. Perlu ada training/diskusi dengan masyarakat pengguna pompa secara periodik untuk membahas /konsolidasi permasalahan di lapangan.

4. Celah yang ada pada katup limbah diatur agar jangan terlalu lebar/ disarankan lebih kurang $4 \mathrm{~mm}$.

\section{b. Saran}

1. Untuk menghindar kemacetan pompa, reservoir awal harus diberi tutup agar kotoran daun tidak masuk dalam air dan bisa menimbulkan penyumbatan.

2. Air dari reservoir awal harus dilengkapi dengan kawat kasa D-1cm untuk menghindari masuknya kotoran dalam tabung tekan.

3. Dalam hal renovasi pipa pesat, diusahakan pipa jenis galvanis dengan ketebalan medium keatas.

4. Ada solusi bahan karet untuk katup limbah yaitu karet setara dengan karet bahan bekas karet konveyer.

5. Bandul otomatis pompa sebaiknya dibuat dari bahan yang tahan gesek karena bandul tersebut selalu bergesekan dengan as katup limbah. 
6. Untuk menjaga dari kerja katup limbah selalu vertikal, sebaiknya portal as limbah dipilih besi yang tahan gesek, agar as bisa bekerja secara vertikal.

7. Untuk menghindari kerusakan pipa pesat, harus dijamin fungsi katup udara bisa bekerja optimal dan untuk menghindari hammer water yang kurang teredam akibat fungsi udara sebagai peredam tidak berfungsi.

8. Katup antar diposisikan jangan terlalu banyak belokan agar energi tidak banyak yang hilang serta bisa lebih optimal.

\section{DAFTAR PUSTAKA}

Bambang Tri Atmodjo. 1996. Hidraulika I. Edisi ke 2. Yogyakarta: Beta Offset.

Gere, M.J., Timoshenko, S.P., dan Wospakrik, H.J. 1987. Mekanika Bahan. Edisi kedua Versi S1. Jilid I. Jakarta: Penerbit Erlangga. 
44 WARTA, Vol.10, No. 1, Maret 2007: 36 - 42 
46 WARTA, Vol.10, No. 1, Maret 2007: 36 - 42 